\title{
A Kinetic Study on Solvolysis of Diphenyl Thiophosphorochloridate
}

\author{
Han Joong Koh, ${ }^{*}$ Suk Jin Kang, and Dennis N. Kevill \\ Department of Science Education. Jeoniu National University of Education, Jeonju $560-757$. Korea \\ E-mail: hankohajme.kr \\ ${ }^{\dagger}$ Department of Chemistrvand Biochemistrv, Northern Illinois Universit. DeKalb, Illinois. U.S.A. \\ Received December 16 2008. Accepted December 24, 2008
}

\begin{abstract}
Rates of solvolyses of diphenyl thiophosphorochloridate $\left((\mathrm{PhO})_{2} \mathrm{PSCl}, \mathbf{1}\right)$ in ethanol, methanol, and aqueous binary mixtures incorporating ethanol, methanol, acetone and 2,2,2-tritluoroethanol (TFE) are reported. For four representative solvents, studies were made at several temperatures and activation parameters were determined. The 30 solvents gave a reasonably precise extended Grunwald-Winstein plot, correlation coefficient $(R)$ of 0.989 . The sensitivity values $(l=1.29$ and $m=0.64)$ of diphenyl thiophosphorochloridate $\left((\mathrm{PhO})_{2} \mathrm{PSCl}, 1\right)$ were similar to those obtained for diphenyl phosphorochloridate $\left((\mathrm{PhO})_{2} \mathrm{POCl}, 2\right)$, diphenylphosphinyl chloride $\left(\mathrm{Pl}_{2} \mathrm{POCl}, 3\right)$ and diphenylthiophosphinyl chloride $\left(\mathrm{Ph}_{2} \mathrm{PSCl}, 4\right)$. As with the previously studied of $\mathbf{3} \sim \mathbf{4}$ solvoly ses, an $\$_{\times} 2$ pathway is proposed for the solvolyses of diphenyl thiophosphorochloridate (1). The activation parameters, $\Delta \mathrm{H}^{ \pm}(=$ $\left.11.6 \sim 13.9 \mathrm{kcal} \cdot \mathrm{mol}^{-1}\right)$ and $\Delta \mathrm{S}^{ \pm}\left(=-32.1 \sim-42.7 \mathrm{cal} \cdot \mathrm{mol}^{-1} \cdot \mathrm{K}^{-1}\right)$, were determined, and they were in line with values expected for an $S_{<} 2$ reaction. The large kinetic solvent isotope effects (KSIE, 2.44 in MeOH/MeOD and 3.46 in $\mathrm{H}_{2} \mathrm{O} / \mathrm{D}_{2} \mathrm{O}$ ) are also well explained by the proposed $\mathrm{S}_{\mathrm{v}} 2$ mechanism.
\end{abstract}

Key Wonds: Diphenyl thiophosphorochloridate, Extended Grunwald-Winstein equation. S:2 mechanism

\section{Introduction}

Phosphoryl transfer from phosphate monoesters and diesters is an important class of reaction that is involved in many aspects of chemistry and biochemistry ranging from organic synthesis to enzyme catalyzed reactions such as DNA replication and repair. 'A considerable amount of work has been carried out to clarity the problem as to whether phosphoryl transfer reactions proceed concertedly with a single transition state (TS) or stepwise with a pentacoordinated phosphorane intermediate. ${ }^{1.3}$

Bourne and Williams, ${ }^{\text {a }}$ and Skoog and Jencks ${ }^{2 t}$ measured the rates of the pyridinolyses of phosphoryl py ridinium compounds and used the slopes. $\beta_{\text {muc }}$ and $\beta_{\mathrm{g}}$ of the Bronsted plots. as a probe of the existence of intermediates in phosphoryl transfer reactions. They showed that the most likely mechanism is a concerted substitution reaction with an "exploded" TS, with weak bonds to both the attacking and leaving groups.

The Grunwald-Winstein equation in its original form ${ }^{3}$ correlates the rates of solvolyses of ionization reactions against the solvent ionizing power values. ${ }^{4}$ Whereas the Hammett equation involves changes in a remote constituent under otherw ise constant conditions. this equation involves changes in the solvent composition under otherwise constant conditions. The Grunwald-Winstein equation can be extended to cover reactions in which the solvent also acts as a nucleoplile by the addition of a second term, involving a scale of solvent nucleophilicity." The basic philosophy of this extension is same as that of the Taft equation. which extends the Hammett equation by adding a second term involving a scale of steric parameters.

The extended Grunwald-Winstein equation can be expressed as in eq. $\mathrm{l}: \mathrm{k}$ and $\mathrm{k}_{\circ}$ represent the specific rates of solvolysis of a substrate RX in a given solvent and in the standard solvent ( $80 \%$ ethanol), respectively: I is the sen- sitivity of the solvolysis towards changes in solvent nucleophilicity $\left(\mathrm{N}_{\mathrm{T}}\right):^{5} m$ is the sensitivity of the solvolysis towards changes in solvent ionizing power ( $\mathrm{Y}_{\mathrm{X}}$. for a leaving group $\mathrm{X}){ }^{+}$and $\mathrm{c}$ is a constant (residual) term.

$$
\log \left(\mathrm{k} / \mathrm{k}_{\mathrm{i}}\right)=/ \mathrm{N}_{\mathrm{T}}+m \mathrm{Y}_{\mathrm{X}}+\mathrm{c}
$$

Previous studies by Kevill and co-workers have been conducted with diphenyl phosphorochloridate $(\mathrm{PhO})_{2} \mathrm{POCl}$. 2. ${ }^{6}$ diary $\mathrm{l}^{6}$ and dimethyl phosphorochloridates. $(\mathrm{RO})_{2} \mathrm{POCl}$, the sulfur-for-oxygen substituted dimethyl phosphorochloridothionate, (MeO) $2 \mathrm{PSCl}{ }^{*} \mathrm{~N}, \mathrm{~N}, \mathrm{~N}, \mathrm{~N}$ '-tetramethyldiamidophosphorocluloridate. $\left(\mathrm{Me}_{2} \mathrm{~N}\right) \mathrm{POCl}^{8}$ and diphenylphosplinyl chloride. $\mathrm{Ph}_{2} \mathrm{POCl} .3{ }^{9}$ The extended Gnunwald- Winstein plot for solvolyses of those substrates containing the P-atom as the reaction center, led to acceptable correlations with very sinular $l$ and $m$ values except for the poorly correlated solvoly ses of diaryl phosphorochloridates with phenyl or $p$-chlorophenyl as the aryl group." The mechanisms of reactions of phosphinothioyl compounds such as diphenyl thiophosphorochloridate ((PhO) $2 \mathrm{PSCl}, 1)$ have been less studied, in spite of their importance as highly reactive chemical intermediates. ${ }^{-i}$

In this work, to gain further understanding of the mechanism of phosphoryl transfer, we carried out kinetic investigations of the solvolysis of diphenyl thiophosphorochloridate $\left((\mathrm{PhO})_{2} \mathrm{PSCl} .1\right)$ in a variety of pure and binary solvents at $55.0^{\circ} \mathrm{C}$. eq. 2 . Specifically. we were interested in the difference depending on a phosphoryl $(\mathrm{P}=\mathrm{O})$ or thiophosphory 1

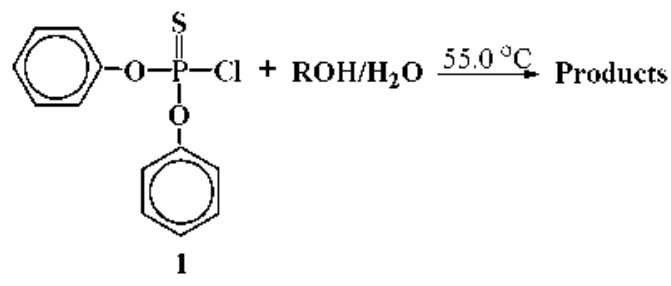


$(\mathrm{P}=\mathrm{S})$ of the $\mathrm{P}$-atom as the reaction center of the substrates $(\mathbf{1} \sim \mathbf{4})$. In addition to the application of the extended GrunwaldWinstein equation to the specific rates, the influence of the temperature on the specific rate (for four solvents) allows enthalpies and entropies of activation to be calculated. Measurements in deuterated methanol (MeOD) and deuterated water $\left(\mathrm{D}_{2} \mathrm{O}\right)$ also allow the determination of the kinetic solvent isotope effect (KSIE). This study could be helpful in clarifying the phosphoryl transfer mechanism. as well as to compare the reactivities among diphenyl phosphorochloridate $\left((\mathrm{PhO})_{2}{ }^{-} \mathrm{POCl} .2\right)^{6}$ diphenylphosphinyl chloride $\left(\mathrm{Pl}_{-}-\right.$ $\mathrm{POCl}, 3)^{6}$ and diphenty lthiophosphinyl chloride $\left(\mathrm{Pl}_{2} \mathrm{PSCl}, 4\right) .{ }^{\mathrm{ij}}$

Table 1. Specific rates of solvolysis ( $\mathrm{k}$ ) of diphenyl thiophosphorochloridate ((PhO) $\mathrm{PSCl}, 1)^{\prime \prime}$ at $55.0^{\circ} \mathrm{C}$ and $\mathrm{N}_{\mathrm{T}}$ and $\mathrm{Y}_{\mathrm{Cl}}$ values of the solvents.

\begin{tabular}{|c|c|c|c|}
\hline Solvent ${ }^{5}$ & $10^{3} \mathrm{k}^{c}\left(\mathrm{~s}^{-1}\right)$ & $\mathrm{N}_{\mathrm{T}}^{d}$ & $Y_{C l}^{6}$ \\
\hline $100 \% \mathrm{EtOH}$ & $0.0585 \pm 0.0007$ & 0.37 & -2.52 \\
\hline $90 \% \mathrm{EtOH}$ & $0.526 \pm 0.003$ & 0.16 & -0.94 \\
\hline $80 \% \mathrm{EtOH}$ & $0.789 \pm 0.007$ & 0.00 & 0.00 \\
\hline $70 \% \mathrm{EtOH}$ & $1.10 \pm 0.03$ & -0.20 & 0.78 \\
\hline $60 \% \mathrm{EtOH}$ & $1.64 \pm 0.04$ & -0.38 & 1.38 \\
\hline $50 \% \mathrm{EtOH}$ & $2.41 \pm 0.07$ & -0.58 & 2.02 \\
\hline $40 \% \mathrm{EtOH}$ & $4.58 \pm 0.04$ & -0.74 & 2.75 \\
\hline $20 \% \mathrm{EtOH}$ & $10.2 \pm 0.3$ & -1.16 & 4.09 \\
\hline $100 \% \mathrm{MeOH}^{\prime}$ & $0.205 \pm 0.004$ & 0.17 & -1.20 \\
\hline $90 \% \mathrm{MeOH}$ & $1.12 \pm 0.03$ & -0.01 & -0.20 \\
\hline $80 \% \mathrm{MeOH}$ & $2.18 \pm 0.05$ & -0.06 & 0.67 \\
\hline $70 \% \mathrm{MeOH}$ & $2.75 \pm 0.06$ & -0.40 & 1.46 \\
\hline $60 \% \mathrm{MeOH}$ & $4.26 \pm 0.05$ & -0.54 & 2.07 \\
\hline $50 \% \mathrm{MeOH}$ & $7.25 \pm 0.06$ & -0.75 & 2.70 \\
\hline $40 \% \mathrm{MeOH}$ & $11.6 \pm 0.3$ & -0.87 & 3.25 \\
\hline $20 \% \mathrm{MeOH}$ & $19.7 \pm 0.5$ & -1.23 & 4.10 \\
\hline $95 \%$ Acetone & $0.00178 \pm 0.00005$ & -0.49 & -3.19 \\
\hline $90 \%$ Acetone & $0.0204 \pm 0.0004$ & -0.35 & -2.39 \\
\hline $80 \%$ Acetone & $0.141 \pm 0.003$ & -0.37 & -0.83 \\
\hline $70 \%$ Acetone & $0.417 \pm 0.006$ & -0.42 & 0.17 \\
\hline $60 \%$ Acetone & $0.776 \pm 0.008$ & -0.52 & 1.00 \\
\hline $50 \%$ Acetone & $2.02 \pm 0.05$ & -0.70 & 1.73 \\
\hline $40 \%$ Acetone & $3.74 \pm 0.07$ & -0.83 & 2.46 \\
\hline $30 \%$ Acetone & $6.35 \pm 0.07$ & -0.96 & 3.21 \\
\hline $20 \%$ Acetone & $10.8 \pm 0.3$ & -1.11 & 3.77 \\
\hline $10 \%$ Acetone & $25.9 \pm 0.4$ & -1.23 & 4.28 \\
\hline $100 \% \mathrm{H}_{2} \mathrm{O}^{\mathrm{g}}$ & $10.2 \pm 0.3$ & -1.38 & 4.57 \\
\hline $80 \% \mathrm{TFE}^{\prime \prime}$ & $0.102 \pm 0.003$ & -2.19 & 2.90 \\
\hline $70 \% \mathrm{TFE}$ & $0.154 \pm 0.004$ & -1.98 & 2.96 \\
\hline $50 \% \mathrm{TFE}$ & $0.525 \pm 0.003$ & -1.73 & 3.16 \\
\hline
\end{tabular}

Unless otherwise indicated, a $10^{-3} \mathrm{M}$ solution of the substrate in the indicated solvent. also containing $0.1^{\circ}, \mathrm{CH}_{2} \mathrm{CN}$ within the solvent. "On a yolume-volume basis at $25.0^{\circ} \mathrm{C}$. "With associated standard deviations. ${ }^{d}$ Values from ref. 5 . ${ }^{e}$ Values from ref. 4 . Value for $\mathrm{k}$ of $0.0840(=$ $0.0005) 10^{-3 .} \mathrm{s}^{-1}$ in methanol-d (MeOD), corresponding to $\mathrm{K}_{\mathrm{YeOH}} \mathrm{k} \mathrm{kMOD}$ value of $2.44=0.06$ [with associated standard error (Čmpler. T. B.: Yoh. J. H. Chemical Computations and Error. Wilev: New' York. 1940: p 178) ] Value for $k$ of $2.95( \pm 0.04) \cdot 10^{-3} \mathrm{~s}^{-1}$ in $\mathrm{D}_{2} \mathrm{O}$. comesponding to $\mathrm{k}_{2} \mathrm{O} \mathrm{k}_{\mathrm{D}, \mathrm{O}}$ value of $3.46 \pm 0.05$. $\mathrm{On}$ a weight-weight basis at $25.0^{\circ} \mathrm{C}$.

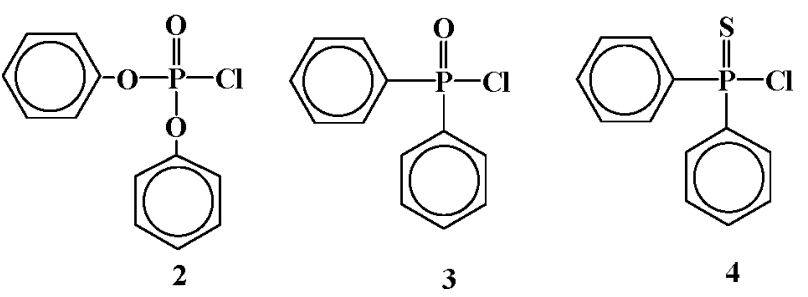

\section{Results and Discussion}

The specific rates of solvolysis of 1 have been deternined in 30 solvents at $55.0^{\circ} \mathrm{C}$. The solvents consisted of ethanol. methanol, and binary mixtures of water with ethanol, methanol. acetone and TFE. The specific rates of solvolysis are presented in Table l. together with $\mathrm{N}_{T}^{5}$ and $\mathrm{Y}_{C l}{ }^{4}$ values. The specific rates of solvolysis of 1 were found to be independent of the initial concentration of the substrate. as shown in Table 2.

For four solvents, specific rates of solvoly sis were measured at three additional temperatures. and these values are reported in Table 3. The enthalpies and entropies of activation for each solvolysis calculated using all four values are also presented in Table 3 .

In the present study, we are concemed with the specific rates of the solvolyses represented in eq. 2. In most solvents. the reactions were reasonably fast. and therefore an apparatus allowing a rapid response to the changes in conductivity ${ }^{11}$ was a convenient way of following the extent of reaction as a function of time. In order to promote a rapid dissolution in the solvent. the substrate was usually added as a small volume of a concentrated stock solution in acetonitrile. such that the reaction solution contained about $0.1 \%$ acetonitrile.

The specific rates were observed to increase with increasing water content for binary aqueous mixtures. The specific rate of ethanolysis of 1 was lower (extrapolated value: $\mathrm{k}=$ $2.30 \times 10^{-6} \mathrm{~s}^{-1}$ at $0.0^{\circ} \mathrm{C}$. experimental value: $\mathrm{k}=8.22 \times 10^{-6} \mathrm{~s}^{-1}$ at $\left.25.0^{\circ} \mathrm{C}\right)$ than that of ethanolysis of $2^{6}\left(\mathrm{k}=4.8 \times 10^{-5} \mathrm{~s}^{-1}\right.$ at $0.0^{\circ} \mathrm{C}$ ). This means that in the reaction of 1 . eq. 2 , the solvents are somewhat loosely bound in transition state (TS) and the extent of bond cleavage of the leaving group $(\mathrm{Cl})$ at the TS is rather low: The difference in the magnitude. i.e.. a lower rates of solvolysis of $\mathbf{1}$ than of solvolysis of $\mathbf{2}$ reflects that. under similar conditions, the $\mathrm{P}=\mathrm{S}$ group favours the $\mathrm{Cl}$-bonded

Table 2. Constancy of the specific rates of solvolysis (k) of diphenyl thiophosphorochloridate ( $\left.\mathrm{PhO})_{2} \mathrm{PSCl}, \mathbf{1}\right)$ with variation of the concentration of the substrate at $55.0^{\circ} \mathrm{C}$

\begin{tabular}{lcc}
\hline Solvent & {$\left[(\mathrm{PhO})_{2} \mathrm{PSCl}\right], \mathrm{M}^{\sigma}$} & $10^{4} \mathrm{k}^{b}, \mathrm{~s}^{-1}$ \\
\hline \multirow{2}{*}{$100 \%$ EtOH } & 0.540 & $0.586 \pm 0.006$ \\
& 1.042 & $0.580 \pm 0.007$ \\
& 2.162 & $0.589 \pm 0.007$ \\
& 0.540 & $7.88 \pm 0.06$ \\
& 1.042 & $7.92 \pm 0.06$ \\
& 2.162 & $7.87 \pm 0.08$ \\
\hline \multirow{3}{*}{$50 \%$ EtOH } & 0.540 & $24.3 \pm 0.6$ \\
& 1.042 & $24.8 \pm 0.8$ \\
& 2.162 & $24.2 \pm 0.8$ \\
\hline
\end{tabular}

${ }^{a}$ Concentration of stock solution in $\mathrm{CH}_{3} \mathrm{CN}$, prior to addition to solvent (see experimental). ${ }^{b}$ The $k$ values are the averages of more than two runs and errors are standard deviations. 
Table 3. Specific rates and activation parameters for the solvolvsis of diphenyl thiophosphorochloridate $\left((\mathrm{PhO})_{2} \mathrm{PSCl}, 1\right)^{a}$ in pure and aqueous solvents at various temperatures

\begin{tabular}{|c|c|c|c|c|}
\hline Solvent & Temperature $\left({ }^{\circ} \mathrm{C}\right)$ & $10^{s} \mathrm{k}^{-b}\left(\mathrm{~s}^{-1}\right)$ & $\Delta \mathrm{H}^{ \pm}\left(\mathrm{kcal} \cdot \mathrm{mol}^{-1} \mathrm{j}^{\mathrm{r}}\right.$ & $-\Delta \mathrm{S}^{ \pm}\left(\mathrm{cal} \cdot \mathrm{mol}^{-1} \cdot \mathrm{K}^{-1}\right)^{\mathrm{c}}$ \\
\hline $100 \% \mathrm{EtOH}$ & $\begin{array}{l}25 \\
35 \\
45 \\
55\end{array}$ & $\begin{array}{c}0.872 \pm 0.002 \\
1.57 \pm 0.003 \\
2.91 \pm 0.004 \\
585 \pm 0.007\end{array}$ & $11.6 \pm 0.6$ & $42.7 \pm 1.9$ \\
\hline $80 \% \mathrm{EtOH}^{3}$ & $\begin{array}{l}25 \\
35 \\
45 \\
55\end{array}$ & $\begin{array}{l}8.36 \pm 0.03 \\
17.9 \pm 0.4 \\
37.2 \pm 0.4 \\
78.9 \pm 0.7\end{array}$ & $13.9 \pm 0.2$ & $32.1 \pm 0.8$ \\
\hline $100 \% \mathrm{MeOH}$ & $\begin{array}{l}25 \\
35 \\
45 \\
55\end{array}$ & $\begin{array}{l}2.41=0.02 \\
4.93 \pm 0.03 \\
9.66 \pm 0.03 \\
20.5 \pm 0.04\end{array}$ & $13.2 \pm 0.4$ & $35.6 \pm 1.3$ \\
\hline $80 \%$ Acetone $e^{t}$ & $\begin{array}{l}25 \\
35 \\
45 \\
55\end{array}$ & $\begin{array}{l}2.04 \pm 0.02 \\
3.98 \pm 0.03 \\
7.41 \pm 0.04 \\
14.1 \pm 0.3\end{array}$ & $11.8 \pm 0.2$ & $40.3 \pm 0.6$ \\
\hline
\end{tabular}

"A $10^{\circ} \mathrm{M}$ solution of the substrate in the indicated solvent. also containing $0.1^{0} .0 \mathrm{CH}_{3} \mathrm{CN}$. "With associated standard deviation. "The activation parameters are accompanied by the standard error. "On a volume-volume basis at $25.0^{\circ} \mathrm{C}$.

nucleofuge $(\mathrm{Cl})$ expulsion less than the $\mathrm{P}=\mathrm{O}$ group

According to the inductive effects of $\mathrm{Ph}\left(\sigma_{\mathrm{I}}=0.12\right)^{12}$ and $\mathrm{PhO}\left(\sigma_{\mathrm{I}}=0.40\right)^{12}$ ligands. we can expect that the rate for the ethanolysis of 1 is much faster than that of 4 with solely considering the positive charge of the reaction center $\mathrm{P}$ atom. However, the observed rate ratio of $\mathrm{k}(\mathrm{t}) / \mathrm{k}(1)$ was 12 (in $100 \%$ ethanol at $55.0^{\circ} \mathrm{C}$ ). This is opposite to expectation. implying that the reaction rate does not depend only on the positive charge of the reaction center $\mathrm{P}^{2 \mathrm{k}}$

In the case of 4 . two phenyl groups are attached to the reaction center $\mathrm{P}$ atom, whereas oxygen atoms are intervening between the reaction center $P$ and the phenyl group in 1 . As a result. the steric hindrance in + would be much larger than that in 1 when the solvent nucleophile attack the reaction center opposite to the $\mathrm{Cl}$ leaving group i.e.. backside nucleophilic

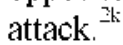

Some phosphate systems are more reactive than their thiophosphate counterparts by two or more orders of magnitude. ${ }^{13}$ Phosphinate sy stems are generally less sensitive to $\mathrm{S}$ substitution in the $\mathrm{P}=\mathrm{O}$ bond than phosphate systems: $\mathrm{k}_{\mathrm{P}=\mathrm{l} .} / \mathrm{k}_{\mathrm{P}=\mathrm{S}}<10$ for the alkaline hydrolysis in $60 \%$ DME- $\mathrm{H}_{2} \mathrm{O}$ and $\mathrm{H}_{2} \mathrm{O}$ in a series of alkyl phosphinates ${ }^{14}$ and $\mathrm{k}_{\mathrm{r}-\mathrm{C}} / \mathrm{k}_{\mathrm{P}-\mathrm{S}}=$ $2.4-5.2$ for the hydrolysis of $\left(\mathrm{CH}_{3}\right)_{2} \mathrm{P}(\mathrm{O}) \mathrm{OPhX}$ and $\left(\mathrm{CH}_{3}\right)_{-}=$ $\mathrm{P}(\mathrm{S}) \mathrm{OPhX}{ }^{-j}$ Our rate ratio of $\mathrm{k}_{\mathrm{P}=\mathrm{S}}(\mathbf{2}) / \mathrm{k}_{\mathrm{P}=\mathrm{S}}(\mathbf{1})$ in ethanoly sis of 21 (at $0.0^{\circ} \mathrm{C}$ ) is consistent with previous work. ${ }^{15}$ In particular. it is in excellent agreement with a very similar value of 34 (at $25.0^{\circ} \mathrm{C}$ ) for the corresponding methyl esters. The $\mathrm{P}=\mathrm{O}$ systems are generally more reactive than their $\mathrm{P}=\mathrm{S}$ counterparts for several reasons. including the so-called thio effect which is mainly the electronegativity difference between $\mathrm{O}$ and $\mathrm{S}$ which favors $\mathrm{O}$ over $\mathrm{S}$.

The activation parameters for solvoly sis of $\mathbf{1}$ are shown in Table 3 . The values of $\Delta \mathrm{H}^{\mp}$ and $\Delta \mathrm{S}^{\dot{*}}$ were respectively obtained from the slope and intercept of Eyring plots by least-squares analysis. The values of $\Delta \mathrm{H}^{\dot{*}}\left(=11.6 \sim 13.9 \mathrm{k} \cdot \mathrm{cal} \cdot \mathrm{mol}^{-1}\right)$ are relatively low, whereas the values of $\Delta S^{ \pm}(=-32.1 \sim-42.7 \mathrm{cal}$. $\mathrm{mol}^{-1} \cdot \mathrm{K}^{-\mathrm{j}}$ ) are large and negative. This observation lies in the range of those for typical $\mathrm{S}_{\mathrm{\gamma}} 2$ reactions.

Halmann $^{18}$ found. for the ethanoly sis of the related diethylphosphinyl chloride. Et $2 \mathrm{POCl}$, that the specific rate of solvoly sis was dependent upon the concentration of the substrate for the range from $2.5 \times 10^{-3}$ to $17 \times 10^{-3} \mathrm{M}$. We found no perturbation of this type over a threefold variation at our lower concentrations $\left(0.5 \sim 2 \times 10^{-2} \mathrm{M}\right)$ of 1 undergoing solvolysis in $100 \%$ ethanol. $80 \%$ or $50 \%$ ethanol. Table 2 . There were also no concentration dependent specific rate perturbation for solvolyses of $3^{9}$ or 4 .

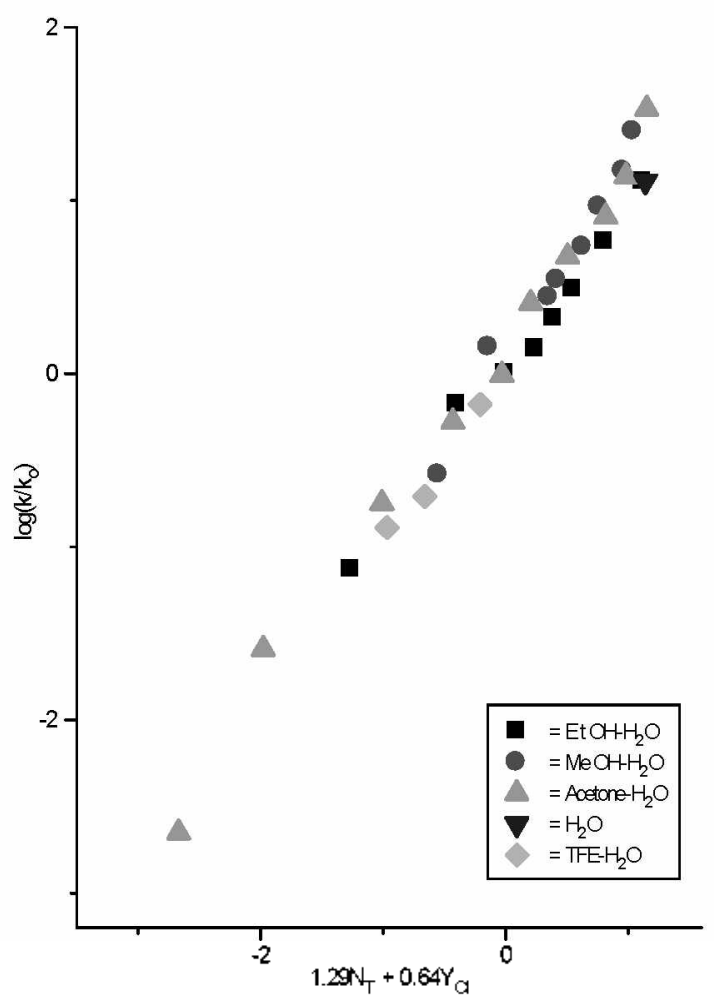

Figure 1. Plot of $\log \left(\mathrm{k} \mathrm{k}_{1}\right)$ for solvolyses of diphenyl thiophosphorochloridate at $55.0^{\circ} \mathrm{C}$ against $\left(1.29 \mathrm{~N}_{\mathrm{T}}+0.64 \mathrm{Y}_{\mathrm{Cl}}\right)$ 
Table 4. Coefticients from the extended Gnunwald-Winstein equation (1) conelations of the specific rates of solvolysis of diphenyl thiophosphorochloridate ((PhO) $\mathrm{PSCl}, 1)$ at $55.0^{\circ} \mathrm{C}$ and a comparison with the corresponding values for other solvolvtic displacements of chloride ion from phosphorus (V)

\begin{tabular}{|c|c|c|c|c|c|}
\hline Substrate & $11^{4}$ & $1^{b}$ & $m^{b}$ & $c^{b}$ & $\mathrm{R}^{c}$ \\
\hline$(\mathrm{PhO})_{2} \mathrm{PSCl}$ & 30 & $1.29 \pm 0.07$ & $0.64 \pm 0.02$ & $0.11 \pm 0.04$ & 0.989 \\
\hline $\mathrm{Ph}-\mathrm{PSCl}^{l}$ & 29 & $1.03 \pm 0.08$ & $0.66 \pm 0.05$ & $-0.06 \pm 0.08$ & 0933 \\
\hline $\mathrm{Ph}_{2} \mathrm{PSCl}^{e}$ & 25 & $1.00 \pm 0.04$ & $0.64 \pm 0.03$ & $0.03 \pm 0.04$ & 0.983 \\
\hline $\mathrm{Ph}: \mathrm{POCl}^{\prime}$ & 31 & $1.44 \pm 0.13$ & $0.58 \pm 0.09$ & $0.15 \pm 0.14$ & 0.920 \\
\hline $\mathrm{Ph}=\mathrm{POCl}^{e}$ & 27 & $1.42 \pm 0.10$ & $0.54 \pm 0.07$ & $0.32 \pm 0.11$ & 0.956 \\
\hline $\mathrm{Ph}_{2} \mathrm{PCl}^{\frac{6}{*}}$ & 29 & $1.31 \pm 0.14$ & $0.51 \pm 0.09$ & $0.12 \pm 0.14$ & 0.899 \\
\hline $\mathrm{Pl} \leqslant \mathrm{PCl}^{p}$ & 25 & $1.25 \pm 0.09$ & $0.46 \pm 0.06$ & $0.24 \pm 0.09$ & 0.954 \\
\hline$\left(\mathrm{MeO}_{2} \mathrm{POCl}^{\prime \prime}\right.$ & 22 & $1.36 \pm 0.23$ & $0.34=0.13$ & $-0.02 \pm 0.17$ & 0844 \\
\hline$(\mathrm{MeO})_{2} \mathrm{POCl}^{e . h \gamma}$ & 18 & $1.24 \pm 0.14$ & $0.45 \pm 0.08$ & $0.18 \pm 0.11$ & 0.941 \\
\hline$(\mathrm{MeO})_{2} \mathrm{PSCl}^{h}$ & 31 & $1.21 \pm 0.10$ & $0.60 \pm 0.04$ & $0.22 \pm 0.07$ & 0.943 \\
\hline$\left(\mathrm{MeO}_{2} \mathrm{PSCl}^{e, h}\right.$ & 28 & $1.16 \pm 0.08$ & $0.55 \pm 0.03$ & $0.30 \pm 0.06$ & 0966 \\
\hline$\left(\mathrm{Me}_{2} \mathrm{~N}\right)_{2} \mathrm{POCl}^{\prime}$ & 31 & $1.20 \pm 0.07$ & $0.69 \pm 0.04$ & $0.03 \pm 0.32$ & 0.958 \\
\hline$\left(\mathrm{Me}_{2} \mathrm{~N}\right)_{2} \mathrm{POCl}^{e . i}$ & 27 & $1.14 \pm 0.05$ & $0.63 \pm 0.03$ & $0.17 \pm 0.21$ & 0.982 \\
\hline$(\mathrm{PhO})_{2} \mathrm{POCl}$ & 38 & $1.72 \pm 0.18$ & $0.68 \pm 0.06$ & $0.42 \pm 0.15$ & 0.885 \\
\hline$\left(\mathrm{p}-\mathrm{ClC}_{6} \mathrm{H}_{4} \mathrm{O}\right)_{2} \mathrm{POC}^{\prime}$ & 31 & $1.79 \pm 0.20$ & $0.58 \pm 0.08$ & $0.11 \pm 0.18$ & 0.863 \\
\hline
\end{tabular}

"Number of data points. "From eq. 1. "Correlation coefficient. "From ref. 10. "Data points for TFE-ethanol mixtures excluded. ${ }^{g}$ From ref. $9 .{ }^{s}$ From ref. 32. ${ }^{\prime}$ From ref. $7 .{ }^{i}$ From ref. $7 .{ }^{j}$ From ref. 11.

The solvolyses of organophosphorus halides have been the subject of several studies. At tetracoordinated phosphorus. reactions with nucleophilic reagents were found to usually proceed by bimolecular mechanisms. ${ }^{19}$ Pentacovalent intermediates or transition states were most frequently proposed though unimolecular mechanisms with a rate determining dissociation of the phosphonis-halogen bond have been occasionally postulated. ${ }^{21}$

A useful tool for quantitatively estimating the rate-controlling influence of nucleophilic participation by solvent during a solvolysis involves the application of the extended Grunwald-Winstein equation. eq. $1 .-9$ Application of eq. 1 to the solvolyses of 1 led to good correlations with only minor dispersal for different binary mixtures. For 30 solvents. values were obtained of $1.29 \pm 0.07$ for $I .0 .64 \pm 0.02$ for $m$. and 0.11 for $c$ : the standard error of the estimate was 0.04 and the $R$ value was 0.989 . Figure 1 . The sensitivity values. $/$ and $m$. and the goodness-of-fit parameters are reported in Table 4 . where they can be compared with literature values for related substrates.

The extended Grunwald-Winstein equation is a very useful indicator of the extent of nucleophilic participation by the solvent, as indicated by the magnitude of the parameter, $l$. which in turn. is directly related to whether a substitution reaction follows a unimolecular or bimolecular pathway. In general. for an ionization reaction without any nucleophilic assistance / will be zero and $m$ close to unity. Whereas for a reaction proceeding with extensive nucleophilic assistance. the / value will be in the region of 0.7 to 1.7 and the $m$ value in the region of 0.3 to $0.5^{3.2}$

Therefore determination of these values will be a valuable source of information concerning the stnicture of the tran- sition state for these solvolyses. ${ }^{23}$ The $l$ and $m$ values for the solvolysis of $\mathbf{1}$ compared with those follows recently reported. after an analysis in terms of eq. 1 , for the specific rates of solvolysis of isopropylsulfonyl chloride $(l=1.28 \pm 0.05, \mathrm{~m}=$ $0.64 \pm 0.03) .^{2-4} N_{1} N$-dimethy lsulfamoyl chloride $(l=1.20 \pm$ $0.04, m=0.72 \pm 0.03)^{2-4} 2$-phenyl-2-ketoethyl tosylate $(l=$ $1.03 \pm 0.04, m=0.56 \pm 0.04)^{23}$ dimethyl thiophosphorochloridate $(l=1.16 \pm 0.08 . m=0.55 \pm 0.03)$, and $N, N, N^{\prime}, N^{\prime \prime}$ tetramethyl dimidophosphorochloridate $(l=1.14 \pm 0.05 . \mathrm{m}=$ $0.63 \pm 0.04$ ) ${ }^{8}$ The / value of 1.29 and the $m$ value of 0.64 for the solvoly sis of 1 were very similar to the previously reported values for the bimolecular solvolyses of other substrates (Table 4), ${ }^{7.24,25}$ which indicates an $\mathrm{S}: 2$ mechanism involving an attack by the solvent at the phosphonus of 1 . The treatment of specific rates for solvolysis of 1 , with both substantial bond making $(l=1.29)$ and bond breaking $(m=0.64)$. also supports a bimolecular mechanism, reflecting appreciable nucleophilic assistance from a solvent nucleoplile.

The / to $m$ ratios have been also suggested as a useful mechanistic criteria. The $l / m$ values from the extended GrunwaldWinstein equation could be classified into three classes of mechanism: $l / m$ values of 1.2 to 2.0 for bimolecular mechanism $\left(\mathrm{S}_{\mathrm{N}} 2\right), 2.3$ to 3.5 for an addition-elimination pathway (A-E), and below 0.7 for an ionization pathway (I). ${ }^{25}$ For the solvolysis of 1 , the $l / m$ value was 2.0 which is very sinular to those of previous studies investigating the solvolyses of isopropylsulfonyl clloride, ${ }^{2} N, N$-dimethyl sulfamoyl chloride. ${ }^{24}$ 2-phenyl-2-ketoethyl-tosylate..$^{35}$ dimethyl thiophosphorochloridate and $N, N, N, N$ '-tetramethyldiamidophosphorochloridate. ${ }^{3}$ and these sinularities suggest the $S: 2$ mechanism.

Bentley, Jones. and $\mathrm{Koo}^{2-2 \mathrm{~d}}$ suggested that dual mechanisms can operate for sulfonyl chloride solvolyses. with the concerted mechanism being favored in more polar solvents. A review ${ }^{28}$ has suggested an interpretation in terms of a concerted bimolecular displacement ( $\mathrm{S} \times 2$ ) mechanism. involving an attack at sulfur by solvent. Our results also seem to be consistent with such an explanation. The similarity of both the $l$ and the $m$ values for an attack at sulfur to those for an attack at the phosphorus of $\mathbf{1}$ gives an indication that the solvolysis of 1 could also proceed wia a concerted mechanism. Scheme 1 .

We found that the use of $N_{T}$ values in conjunction with $Y_{C}$ values leads to acceptable correlations. with $l$ and $m$ values similar to those obtained in analyses of the specific rates of solvolyses for other entries in Table 4 . The only difference is smaller / value for the solvolysis of 1 , possibly reflecting a decreased nucleoplilic participation at the transition state due to reduced electronegativity of the phosphinyl sulfur $(\mathrm{P}=\mathrm{S})$ compared to the $\mathrm{P}=\mathrm{O}$ bond.

In methanol and methanol- $d(\mathrm{MeOD})$, a KSIE $\left(\mathrm{K}_{\mathrm{MecH}} / \mathrm{k}_{\mathrm{MeCT}}\right)$ of $2.44 \pm 0.05$ at $55.0^{\circ} \mathrm{C}$ is observed $\left(\mathrm{k}_{\mathrm{MeCD}}=8.40( \pm 0.22) \times 10^{-5}\right.$ $\left.\mathrm{s}^{-1}\right)$. This result is in the range of values from $1.58 \pm 0.05$ to $2.31 \pm 0.07$ which have been observed ${ }^{-9}$ for the corresponding methanolyses of a series of benzenesulfonyl chlorides at $25.0^{\circ} \mathrm{C}$. in which the reactions are believed to be $\mathrm{S}_{\mathrm{N}} 2$ in character. The methanoly ses of meta- and para-chlorobenzyl chloride and para-nitrobenzyl chloride, believed to be $\mathrm{S}_{\mathrm{N}} 2$ in character. also show values in the $1.49 \pm 0.05$ to $1.89 \pm 0.07$ 


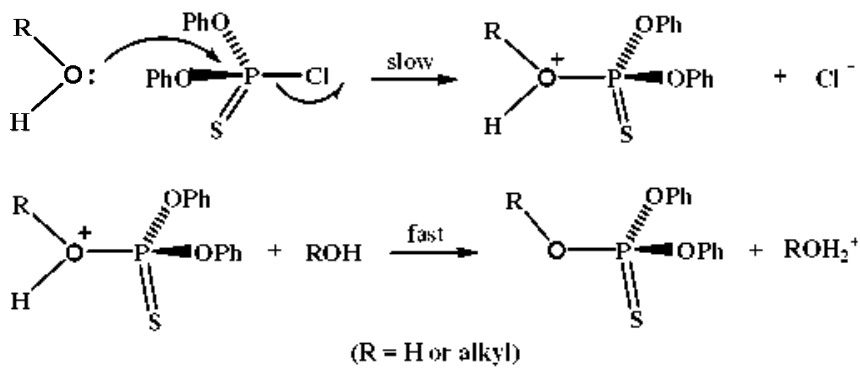

Scheme 1

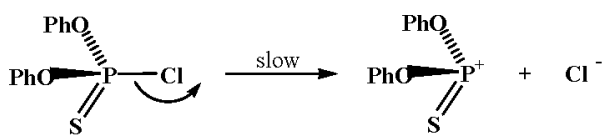

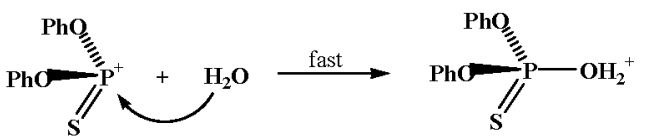

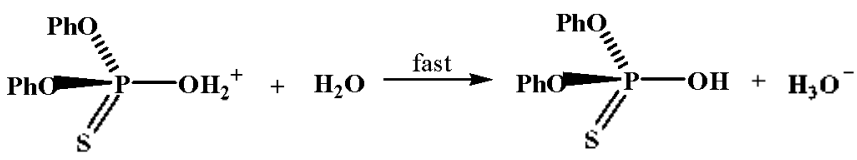

Scheme 2

range ${ }^{30}$ Previous studies have indicated that values in these ranges can be considered as good supporting evidence for the postulation of an $S: 2$ mechanism for a methanolysis. In water $\left(\mathrm{H}_{2} \mathrm{O}\right)$. and deuterated water $\left(\mathrm{D}_{2} \mathrm{O}\right)$ a KSIE of $3.46 \pm 0.05$ at $55.0^{\circ} \mathrm{C}$ is also observed $\left(\mathrm{k}_{\mathrm{D}+1}=2.95( \pm 0.04) \times 10^{-3} \mathrm{~s}^{-1}\right)$. On the basis of the observed KISE value the possibility of a $S_{N} l$ mechanism for the hydrolyses of 1 (Scheme 2) could be excluded. 29.39

\section{Conclusions}

The solvolysis of 1 proceeds rapidly at $55.0^{\circ} \mathrm{C}$ and the progress of reaction as a function of time can be comeniently monitored using a rapid-response conductivity technique. The rates of solvolyses of $\mathbf{1}$ in ethanol. methanol. and aqueous binary mixtures incorporating ethanol, methanol, acetone and TFE are reported. For four typical solvents. activation parameters were determined and the large negative entropies of activation are consistent with a bimolecular process. Kinetic solvent isotope effects for the solvolyses also support the mechanism proposed.

Application of the extended Gnunwald-Winstein equation (eq. 1 ) in 30 solvents led to an / value of 1.29 and an $m$ value of $0.6+$ (correlation coefficient of 0.989 ). These values are shown (Table 4 ) to be similar to previously determined values for micleophilic attack by solvent at phosphorus compounds. They are also. very close to literature values for the solvolyses of sulfonyl cllorides. Previously-studied solvolytic displacements at phosphonıs or sulfur have usually been proposed to follow an $S: 2$ pathway, and such a pathway is also proposed for the solvolyses of 1 , Scheme 1 .

\section{Experimental}

The purification of acetone, methanol, ethanol and TFE were carried out as previously described. ${ }^{3(1)}$ The substrate did not react with the pure acetonitrile within the stock solution.

Diphenyl thiophosphorochloridate 1 was prepared by reacting phenyl phosphorodichloridothionate (Sigma-Aldrich's Rare Chemical Library) with phenol. A solution of phenyl phosphorodichloridothionate $0.01 \mathrm{~mol}$ in $15 \mathrm{~mL}$ of HPLC grade acetonitrile was added to a solution of the required amount of phenol for $0.01 \mathrm{~mol}$ and $0.01 \mathrm{~mol}$ of triethylamine in $15 \mathrm{~mL}$ of the same acetonitrile in an ice bath. The solution was stirred in an ice bath for 2 hours. Triethylanine hydrochloride salt was separated by filtration. Acetonitrile was evaporated and the remaining product was treated with ether and water for work-up. After work-up. anhy drous $\mathrm{MgSO}_{4}$ was added. kept 4 hours. the $\mathrm{MgSO}_{4}$ was removed by filtration and the solvent was removed under reduced pressure. Finally, the product was subjected to column chromatography (ethyl acetate $+n$-hexane) for purification. (PhO) $2 \mathrm{PSCl}:$ m.p. $64-65$ ${ }^{\circ} \mathrm{C}$. Calc. for $\mathrm{C}_{12} \mathrm{H}_{10} \mathrm{O}_{2} \mathrm{PSCl}: \mathrm{C}, 50.62: \mathrm{H}, 3.54$. Found : $\mathrm{C}$. 50.17 : H, $3.30 \%$.

Kinetic nuns were performed with $10 \mu \mathrm{L}$ of the stock solution of the substrate ( $1 \mathrm{M}$ ) and $5 \mathrm{~mL}$ of the reaction solvent. All kinetic runs were performed, at least, in duplicate. The reaction cell was washed with water and acetone several times and dried prior to each run. A $5 \mathrm{~mL}$ portion of solvent was added to the reaction cell and allowed to sit for a few minutes until it reached a temperature equilibrium with the constant temperature bath. A $10 \mu \mathrm{L}$ portion of the stock solution was then added and the reaction cell was shaken vigorously. The change of the conductance in the reaction with time was saved in the computer as a data file.

Rates were measured conductimetrically at $55.0^{\circ} \mathrm{C}$. All kinetic measurements were carried out in a constant temperature bath maintained within $\pm 0.05^{\circ} \mathrm{C}$. The conductivity bridge used in this work was a self-made computer automatic A/D converter conductivity bridge. First-order solvolys sis rate coefficients $\left(\mathrm{k}_{\mathrm{ols}}\right)$, with the solvent in large excess. were determined by a curve fitting analysis of the computer data with a modified version of the Origin Program, which fits conductance vs. time data to the equation $A=A_{\%}+\left(A_{01}-A_{\%}\right)$ $\exp \left(-\mathrm{k}_{\mathrm{cbs}}{ }^{*} \mathrm{t}\right)$, where $A$ is the observed conductivity and $A_{s_{.} .} A_{0}$ $A_{x}$, and $\mathrm{k}_{\text {itts }}$ are iteratively optimized to achieve the best possible least-squares fit.

\section{Refeiences}

1. (a) Page, M:; Willams, A. Organic and Bio-Organic Mechanisms: Longmant: Harlow 1997; Chapters 7-8. (b) Williams, A. Concented Organic and Bio-Organic Hechanisnts; CRC Press: Boca Raton, 2000: Chapter 6. (c) Hudson. R. F. Stricture and 1 fechonism in Organophosphoms Chemistry. Academic Press: New York, 1965. (d) Admiral, S. J.: Schneider, B.: Meyer, P.: Janin, I.; Veron, M; Deville-Bonne, D.; Herschlag, D. Biochemisty 1999, 38,4701. (e) Mol C. D.; Izumi, T:; Mitra, S.; Tainer, J. A. Nature 2000, 403,451 . (f) Hosfield, D. J.; Guan, Y.; Haas, B. I.; Cunningham, R. P.: Tainer, T. A. Cell 1999, 98, 397. (g) Mol, C. D.; Hosfield, D. J.; Tainer, T. A. Hittat Res. 2000, 160,211 . (h) Chapados, B. R:; Chai, Q; Hostield, D. I: Qiu, T.; Shen, B.; 
Tainer, I. A. Mol. Biol, 2001, 307, 541

2. (a) Boune, N.; Williams, A.J. Am. Chem Soc. 1984, 106, 7591. (b) Skoog, M. T.; Tencks, W. P. J. Am. Chem. Soc. 1984, 106 , 7597. (c) Kirbv, A. T.: Varroglis, A. G. J. Am. Chem. Soc. 1967, 89,415. (d) Friedman. J. M.: Freeman. S.: Knowles. J. R. J. Am. Chem. Soc. 1988, 110, 1268. (e) Boume, N.; Chrystiuk, E.: Davis, A. M.: Williams, A. J. Am Chem Soc 1988, 110, 1890. (f) Ba-Saif, S. A.: Waring, M. A: Williams, A. J. Am Chent. Soc. 1990, 112,8115. (g) Hengge, A. C.: Edens, W. A.; Elsing, H. J. Am Chem Soc. 1994, 116, 5045. (h) Hoff, R. H.: Hengge, A. C.J. Org (Chem. 1998, 63, 6680 (i) Gula, A. K.; Lee, H. W.; Lee, I. J. Chem. Soc., Perkin Trans. 2 1999, 765. (j) Hoque, Md. E. U.; Dev, N. K.; Guha, A. K.; Kim, C. K.; Lee, B.-S.; Lee, H. W. Bull. Korean Chent. Soc 2007, 28, 1797. (k) Hoque, Md. E. U.: Lee, H. W. Bull. Korean Chem. Soc. 2007, 28, 936 .

3. Winsten, S.; Grnnwald, E.: Tones, H. W. J. Am. Chem Soc. $1951,73,2700$.

4. (a) Grunwald, E.: Winstein, S. J. Am. Chem. Soc 1948, 70, 846. (b) Bentley, T. W.; Llewellyn, G. Prog. Phvs. Org. Chem. 1990, 17, 121. (c) Kevill, D. N.: D Souza, M. I. J. Chem. Res. Smop. 1993, 174. (d) Bentley, T. W: Carter, G. E. J. Am. Chen. Soc: 1982, 104, 5741 . (e) Koo, I. S.; Bentlex; T. W.; Kang, D. H.; Lee, I.J. Chem. Soc. Perkin Trans. $21991,296$.

5. (a) Kevill, D. N.: Anderson, S. W. J. Org. Chem. 1991, 56, 1845. (b) Kevill, D. N. In Atwances in Ouantitative Structure-Propert Relationships; Charton, M., Ed.; TAI Press: Greenwich, CT, 1996; Vol. 1, pp 81 115.

6. Bentley, T. W.: Ebdon, D.: Llewellyn, G.: Abduljaber, M. H.: Miller, B.: Kevill, D. N. J. Chem. Soc. Dalton Trans. 1997, 3819.

7. Kevill, D. N.; Carver, J. S. Org. Biontol. Chent. 2004, 2, 2040.

8. Kevill, D. N.; Miller, B. J. Org. Chem. 2002, 67,7399

9. Kevill. D. N.: Koh, H. T. J. Phis. Org Chem 2007, 20, 88

10. Koh, H. T.; Kan1g, S. T.; Kevill, D. N. Bull Korean Chem. Soc. 2008, 10, 1927

11. (a) Bentley, T. W: Ebdon, D. N. J. Phys. Org Chem 2001, IH, 759. (b) Koh. H. J.: Han, K. L.; Lee, H. W.: Lee, I. J. Org. Chem. $1998,63,9834$.

12. Charton, M. Prog. Phws. Org. Chem. 1987, 16, 287

13. (a) Neimy sheva, A. A.; Savchik, V: Ermolaeva, M. V.; Knunvants, I. L. Bull. Acad. Sci. LSSR Div. Chem. Sci. (Engt. Transl.) 1968, 2104. (b) Ketelaar, I. A. A.: Gresmann, H. R.: Koopman1s, K. Recl. Trav. Chim. Pays-Bas. 1952, 71, 1253. (c) Chlebowski, J. F.: Coleman, T. E. J. Biol Chem 1974, 247, 7192.

14. Cook, R. D.; Farah, S.; Ghawi, L.; Itani, A.; Rahil, J. Cam. J. Chem. 1986, 64. 1630

15. (a) Bel skii, V. E.: Bezzubova, N. N.: Akamsin, V. D.: Eliseenkov, V. N.; Rizpolozhenskii, N. I.; Puduvik, A. N. Dokt. Akad Kauk. SSSR 1971, 197, 85, Eng. Trans. p 171, (b) Onvido, I.: Swierczek, K.; Purcell, T: Hengge, A. C. J. Am Chen. Soc: 2005, 127,7703. (c) Douglas, K. T. Willianns, A. J. Chem. Soc., Perkin Trans. 21976,515 . (d) Un, I. H.: Akhtar, K. Shin, Y. H.; Han, I. Y. J. Org. Chem 2007, 72, 3823. (e) Cook, R. D.; Daouk, W. A. Haij, A. N.; Kabbani, A.; Kurku, A.; Samaha, M.; Shavban, F.: Tantielian, O. V. Can. J. Chem. 1986, 64, 213
16. (a) Henge A. C. Onyido I. Cum, Org. Chem 2005, 9, 61. (b) Omakor, J. E.: Onyido, I.: VanLoon, G. W.: Buncel, E. J. Chem. Soc. Perlin Trans. 22001. 324. (c) Gregersen. B. A.: Lopez. X.: York, D. M. J. Ant. Chent. Soc. 2003, 125, 7178. (d) Hondal, R. J.: Bruzik, K. S.; Zhao, Z.; Tsai, M. D. J. Am. Chem. Soc. 1997. 119, 5477 . (e) Lee, H. W.; Guha, A. K.; Lee, I. Int. J. Chem. Kinet 2002, 34,632.

17. (a) Lee, I.; Sung, D. D.; Uhm, T. S.; Ryu, Z. H. J. Chent. Soc., Perkin Trons. 2 1989, 1697. (b) Yew, K. H.: Koh, H. J.: Lee, H. W.; Lee, I. J. Chem. Soc. Pewin Trans. 2 1995, 2263

18. Halmann, M. Phosphonis Sulfu: 1988, 40,251.

19. (a) Dostrovsky, I.; Halmann, M. J. Chem. Soc. $1953,5(22$ (b) Dostrovsky, I.; Halmann, M. J. Chem. Soc, 1956, 1004. (c) Corriu, R. J. P. Phosphonts Sulfir 1986, 27, 1. (d) Lanneau, G. F. Phosphonis Sulfu 1986, 27,43.

20. Westheimer, F. H. Acc. Chem Res. 1968, 1, 70.

21. (a) Hall, H. K. Jr. J. Org. Chem. 1956, 21, 248. (b) Wadsworth, W. Jr.: Horton. H. J. Am. Chem. Soc, 1970, $92,3785$.

22. Lee. S. H.: Rhu, C. I.: Kvong. I. B.: Kim. D. K.: Kevill. D. N. Bull. Korean Chem. Soc. 2007, $28,657$.

23. (a) Kevill, D. N.; D'Souza, M. J. J. Org. Chem. 1998, 63, 2120. (b) Krong. J. B.: Park, B. C. Kim. C. B.; Kevill, D. N. J. Org. Chem. 2000, 65, 8051, (c) Kevill, D. N.; D'Souza, M. T. Collect. Czech. Chem. Commm. 1999, 64. 1790. (d) Bentley. T. W: Jones, R. O.: Koo, I. S. J. Chem. Soc. Pewin Trans. $21994,753$. (e) Kevill, D. N.: D'Souza, M. J. J. Phys. Org. Chem. 2002, 15, 881. (f) Kyong, J. B.; Won, H. S.; Lee, Y. H.; Kevill, D. N. Bull. Korean Chem. Soc. 2005, 26,661.

24. Kevill, D. N.; Park, B. C.: Park, K. H.; D:Souza, M. T.; Yaakoubd, L; Mynarski, S. L.; Kyong, T. B. Org. Biontol. Chent 2006, t, 1580

25. Kevill, D. N.: Kim, C. B. J. Org. Chem 2005, 70, 1490.

26. (a) Kyong, J. B.: Kim, Y. G.; Kim, D. K.; Kevill, D. N. Bull. Korem Chent Soc: 2000, 21, 662. (b) Kevill, D. N.; Kyong, J. B.; Weitl, F. L. J. Ong. Chem 1990, 55, 4304. (c) Kyong, J. B.; Rvu, S. H.: Kevill, D. N. Int . . Mot Sci. 2006, 7, 186. (d) Kevill, D. N.; D Souza, M. J. J. Oig. Chem. 2004, 69, 7044 (e) Kyong: J. B.: Won. H. S.: Kevill. D. N. Int. J. M Iol. Sci. $2005,6.87$.

27. (a) Hotfmann, H. M. R. J. Chen. Soc. 1965,6753 . (b) Ingold, C. $\mathrm{K}$. In Structure and Hechanism in Organic Chemistry $2^{\text {nd }} \mathrm{ed}$; Comell University Press: Ithaca, NY, 1969: pp 471-473. (c) Lowry, T. H.: Richardson. K. S. Mechanism and Theon' in Orgonic Chemistry, $3^{\text {rd }}$ ed.; Harper and Row: New York, 1987; pp 373-376

28. Gordon, I. M.: Maskill, H.; Ruasse, M.-F. Chem Soc. Rev, 1989. 18.123

29. Koo, I. S.; Lee, I.; Oh, J. U.; Yang, K. Y; Bentley, T. W. J. Phws. Org. Chem. 1993, 6, 223.

30. Lee, I.; Kol, H. J.; Park, Y. S.; Lee, H. W. J. Chent. Soc., Perkin Trans. 21993.1575.

31. Kevill, D. N.; Kolwyck, K. C.; Weitl, F. L. J. Am. Chem. Soc. $1970,92,7300$

32. Koh, H. T.; Kang, S. J.; Kevill, D. N. Phosphorys, Sulfir, and Silicon 2008, 183, 364. 